\title{
Dietary sources of inorganic microparticles and their intake in healthy subjects and patients with Crohn's disease
}

\author{
Miranda C. E. Lomer ${ }^{*}$, Carol Hutchinson ${ }^{2}$, Sara Volkert ${ }^{2}$, Simon M. Greenfield ${ }^{3}$, Adrian Catterall ${ }^{4}$, \\ Richard P. H. Thompson ${ }^{1}$ and Jonathan J. Powell ${ }^{1,5}$ \\ ${ }^{1}$ Gastrointestinal Laboratory, The Rayne Institute, St Thomas' Hospital, Lambeth Palace Road, London SE1 7EH, UK \\ ${ }^{2}$ Department of Nutrition and Dietetics, Franklin-Wilkins Building, King's College London, 150 Stamford Street, \\ London SE1 9NN, UK \\ ${ }^{3}$ Department of Gastroenterology, Queen Elizabeth II Hospital, Howlands, Welwyn Garden City, Hertfordshire AL7 $4 H Q$, UK \\ ${ }^{4}$ Department of Gastroenterology, Lister Hospital, Coreys Mill Lane, Stevenage, Hertfordshire SG1 4AB, UK \\ ${ }^{5}$ MRC Human Nutrition Research, Elsie Widdowson Laboratory, Fulbourn Road, Cambridge CB1 9NL, UK
}

(Received 29 March 2004 - Revised 2 August 2004 - Accepted 5 August 2004)

\begin{abstract}
Dietary microparticles are non-biological, bacterial-sized particles. Endogenous sources are derived from intestinal Ca and phosphate secretion. Exogenous sources are mainly titanium dioxide $\left(\mathrm{TiO}_{2}\right)$ and mixed silicates (Psil); they are resistant to degradation and accumulate in human Peyer's patch macrophages and there is some evidence that they exacerbate inflammation in Crohn's disease (CD). However, whether their intake differs between those with and without CD has not been studied. We aimed to identify dietary microparticle sources and intakes in subjects with and without CD. Patients with inactive CD and matched general practice-based controls (ninetyone per group) completed $7 \mathrm{~d}$ food diaries. Intake data for dietary fibre and sucrose were compared as positive controls. All foods, pharmaceuticals and toothpastes were examined for microparticle content, and intakes of $\mathrm{Ca}$ and exogenous microparticles were compared between the two groups. Dietary intakes were significantly different between cases and controls for dietary fibre (12 (SD 5) v. 14 (SD 5) $\mathrm{g} / \mathrm{d} ; P=0.001$ ) and sucrose (52 (SD 27) v. 45 (SD 18) g/d; $P=0.04$ ) but not for Ca. Estimated median $\mathrm{TiO}_{2}$ and Psil intakes $(2.5 \mathrm{and} 35 \mathrm{mg} /$ individual per $\mathrm{d}$ respectively, totalling $10^{12}-10^{13}$ microparticles/individual per $\mathrm{d}$ ) were broadly similar to per capita estimates and while there was wide variation in intakes between individuals there was no significant difference between subjects with CD and controls. Hence, if exposure to microparticles is associated with the inflammation of $\mathrm{CD}$, then the present study rules out excess intake as the problem. Nonetheless, microparticle-containing foods have now been identified which allows a low-microparticle diet to be further assessed in CD.
\end{abstract}

Dietary microparticles: Crohn's disease: Titanium dioxide: Silicates: Particulates

Factors that trigger or exacerbate Crohn's disease (CD) remain unclear. Diet has been the subject of much speculation, while stronger evidence supports the role of luminal bacteria in disease maintenance. Epidemiological and molecular studies clearly indicate a genetic predisposition. Intestinal macrophages are activated in early CD (Ellis et al. 1998) and recent data indicate that mutations in a predominantly macrophage protein, namely NOD2 (or CARD-15), are associated with non-colonic disease (Hampe et al. 2002). Although, ex vivo, excessive levels of soluble bacterial products appear to activate NOD2, membrane-bound toll-like receptors are much more sensitive receptors and it seems likely that the NOD family of proteins respond to intracellular (i.e. particulate) triggers (Inohara et al. 2003). Whole or partial bacteria are the obvious candidates for NOD2 engagement, specifically through recognition of peptidoglycan polysaccharide, and surgical diversion data certainly suggest that particulate, but not soluble, factors of the luminal stream exacerbate CD (Powell et al. 1996). Luminal bacteria are present in the human gut at up to $10^{12} / \mathrm{g}$ intestinal contents (Gibson \& Roberfroid, 1995), but their translocation, distinct from their 'association with the mucosa', has been rarely observed in health and has only recently been shown in the inflamed gut of patients with inflammatory bowel disease (Rayment et al. 2003). The mucus layer, secretion of Ig A, junctional complexes and cell surface recognition of bacterial components probably prevents their mass translocation into the intestinal mucosa. However, we have proposed an alternative possibility for the translocation of luminal bacterial products; namely, that non-biological particles, of bacterial size, can adsorb luminal constituents and deliver them to intestinal macrophages relatively unimpeded. We have estimated that $10^{12}-10^{14}$ such particles are 
ingested per individual daily from the typical Western diet with an estimated mucosal uptake of $0.1-1 \%$ (i.e. $10^{9}-10^{12} / \mathrm{d}$ ) (Lomer et al. 2002). These particles are mainly titanium dioxide $\left(\mathrm{TiO}_{2}\right)$ and particulate silicates (including aluminosilicates), termed here as Psil. (The term Psil is used to differentiate particulate silicates from the possibly essential, soluble, monomeric silicate ion $\left(\mathrm{Si}(\mathrm{OH})_{4}, \mathrm{Si}_{\mathrm{m}}\right.$ or often just $\left.\mathrm{Si}\right)$, the aquated oligomeric silicate ion $\left(\mathrm{Si}_{\mathrm{o}}\right)$ or porous elemental $\mathrm{Si}$ that undergoes aqueous dissolution (pSi) (Taylor et al. 1997; Anderson et al. 2003).) The particles are naturally occurring as soil particles but also are added to food, pharmaceuticals and toothpaste as smaller microparticles (defined as $0.1 \mu \mathrm{m}<$ diameter $<3 \mu \mathrm{m}$ ). (The term microparticle is used to describe non-biological particles of $0 \cdot 1-1 \mu \mathrm{m}$ diameter (i.e. 'fine' particles) plus $1-3 \mu \mathrm{m}$ diameter (i.e. small coarse particles) as the size of these can trigger cytoskeletal ruffling and phagocytosis (Kovacsovics-Bankowski et al. 1993). However, in practice the microparticles observed in the intestinal mucosa are almost always $<1 \mu \mathrm{m}$ diameter.) $\mathrm{TiO}_{2}$ is mainly used as a whitening and/or brightening agent and Psil as anti-caking agents; as man-made additives for human ingestion they have active, charged surfaces and are well scavenged by intestinal lymphoid aggregates in the colon and especially the ileum (Harper et al. 1985; Shepherd et al. 1987; Urbanski et al. 1989). They are undegradable and accumulate over time in intestinal macrophages. Based on their temporal, geographical and anatomical distribution we have proposed that they may have a role in CD (Lomer et al. 2002).

In a pilot study we indicated that their removal from the diet may ameliorate disease activity in CD (Lomer et al. 2001). This may occur either because patients have an abnormal response to such microparticles, as previously suggested (Evans et al. 2002), or because patients have a greater exposure (i.e. intake) than the normal population which has not been assessed. It is noteworthy that an increased exposure to fine particles of ambient air is associated with an increased risk of lung disease, CVD and overall mortality (Samet et al. 2000), so it is possible that the same is true for ingested microparticles and the gastrointestinal tract. The aim of the present study was to determine the dietary sources and intakes of $\mathrm{TiO}_{2}$ and Psil in patients with $\mathrm{CD}$ and healthy controls. This is important for two reasons; first, it will enable a particle-free diet to be designed and, second, we can determine whether particulate intake is greater in subjects with $\mathrm{CD}$ compared with controls. To our knowledge, this is the first time that intakes of dietary food additives have been compared between two groups and so novel dietary assessment techniques have also been developed.

Previous dietary studies have consistently shown that the intake of refined carbohydrate, which commonly contains $\mathrm{TiO}_{2}$, is increased in patients with CD (Martini \& Brandes, 1976; Kasper \& Sommer, 1979; Silkoff et al. 1980; Mayberry et al. 1981; Brauer et al. 1983; Jarnerot et al. 1983; Katschinski et al. 1988; Tragnone et al. 1995). Some studies, however, have suffered from a lack of specificity since numerous nutrients have been investigated and findings have not been corrected for multiple comparisons (Martini \& Brandes, 1976; Kasper \& Sommer et al. 1979;
Tragnone et al. 1995). In addition to measuring the intakes of inorganic microparticles in patients with CD $v$. a matched control group we have specifically compared intakes of dietary fibre, sucrose and total sugars. Sucrose intake was investigated, mainly because this serves as a 'positive control' with higher intakes having been widely described before in subjects with CD $v$. controls. Ca intakes were also compared since this element contributes to the formation of endogenous luminal microparticles (as calcium phosphate; Evans et al. 2002; Lomer et al. 2002) and/or may act as a bridging ion for microparticle-bacterial component conjugates (Evans et al. 2002; Lomer et al. 2002). It should be noted that some dietary intake data have recently been published for this cohort (energy, protein, fat, carbohydrate and $\mathrm{Fe}$ ) with only $\mathrm{Fe}$ intakes differing between the two groups (i.e. reduced in CD; Lomer et al. 2004).

\section{Methods}

\section{Subjects}

From September 1999 to August 2000, patients with CD (18-65 years; $n$ 91) were recruited by invitation letter from gastroenterology databases held at Guy's and St Thomas' NHS Trust (London), Queen Elizabeth II Hospital (Welwyn Garden City, Hertfordshire) and The Lister Hospital (Stevenage, Hertfordshire). Randomly selected healthy volunteers with no known history of gastrointestinal disease were similarly recruited from the registered records of general practitioners (GPs) local to the hospitals and were matched to the patients by age ( \pm 5 years), sex, ethnicity, area of residence and social class (Reid, 1980). Ethical permission was obtained from Guy's and St Thomas' NHS Trust and the East and North Hertfordshire NHS Trust.

Prior data on microparticle intake do not exist and so the sample size was calculated to achieve $80 \%$ power at the $5 \%$ significance level for detecting a significant difference of $20 \mathrm{~g} / \mathrm{d}$ in the intake of the most widely studied nutrient in this field, namely sucrose, assuming a SD in each group of $45 \mathrm{~g}$ (Silkoff et al. 1980; Brauer et al. 1983; Tragnone et al. 1995).

\section{Dietary assessment}

A $7 \mathrm{~d}$ food diary (Bingham et al. 1997), as described elsewhere (Lomer et al. 2004), was used to collect data on food intake. At the same time, pharmaceutical, dietary supplement and toothpaste usage were recorded in a separate diary designed by M. C. E. L. (Lomer et al. 2004). Subjects were shown how to document all oral prescribed and over-the-counter medication and dietary supplements, including herbal, vitamin and mineral preparations, recording the dose (as described on the packet or prescription label), proprietary or non-proprietary names, formulation (tablet, syrup etc.) and amount taken per d. For toothpaste usage, subjects were asked to provide details of toothpaste type and brand name, number of sessions teeth were brushed each day and, using multiple-choice tick boxes, the amount of toothpaste used at each brushing (for example, pea-sized to 1 inch). 


\section{Nutrient and dietary microparticle database}

A UK nutrient database was used to calculate energy and nutrient data as described previously (Lomer et al. 2004). Dietary fibre intake was estimated from UK food composition data using the Englyst method (Holland et al. 1991). For refined carbohydrate, intakes of 'total sugars' and sucrose were measured. Total sugars refer to all sugars naturally present in food plus sugars added to foods, including free monosaccharides and disaccharides. 'Sucrose' is defined as the total amount of sucrose in the diet (including table sugar), rather than only sucrose added to manufactured foods. Sucrose constitutes the greatest proportion of total sugars in confectionery, biscuits, cakes and pastries, whereas fructose is primarily found in fruits, vegetables and honey (Department of Health, 1989).

To date, no data have been available for intakes of food-additive $\mathrm{TiO}_{2}$ and Psil from the diet, pharmaceuticals, dietary supplements or toothpaste. In the present study, an extensive database was created using product label information, information provided from manufacturers and a recently developed analytical technique for $\mathrm{TiO}_{2}$ (Lomer et al. 2000).

In the first instance, of the 8294 different foods or brands of foods ingested by all subjects ( $n$ 182) over the $7 \mathrm{~d}$ period, a complete list was created of those that may legally (Jukes, 1997) contain added $\mathrm{TiO}_{2}$ or Psil (4910 brands). Full labelling information was then obtained for almost all these foods and the presence ( $n$ 92) or absence ( $n$ 4474) of $\mathrm{TiO}_{2}$ or Psil was confirmed, which is a legal obligation for the majority of food products in the UK (Jukes, 1997; Lomer, 2002). A few specific brands of foods could not be identified ( $n$ 344) due to insufficient information from the food diary data.

For all pharmaceuticals, dietary supplements and toothpaste used during the $7 \mathrm{~d}$ study period and for all foods that were identified to contain $\mathrm{TiO}_{2}$ or Psil (total 379 products), manufacturers ( $n$ 158) were contacted for quantitative data on the usage of these man-made excipients and food additives (i.e. $\mathrm{TiO}_{2}$ or Psil). Quantitative data were provided by 110 manufacturers for 211 products; laboratory analyses of $\mathrm{TiO}_{2}$ in a subset of foods and pharmaceuticals showed these data to be reliable (Lomer et al. 2000; Lomer, 2002). Qualitative data were provided by twenty manufacturers for eighty-two products, but the remaining manufacturers either did not reply (fifteen manufacturers for fifty-two products) or declined to disclose data (thirteen manufacturers for thirty-four products) as this information was considered proprietary. Therefore, in the present study, we use the terms 'minimum' ingested, using quantitative data only, and 'likely' ingested, using qualitative and quantitative data. When qualitative data only were available (food labels or manufacturer's confirmation), levels were estimated from the average of differently branded but identical products. A similar approach was taken for the few foods that could not be identified by brand.

Only one manufacturer was prepared to disclose data for toothpaste and so we used minimum and maximum likely levels of 0.1 and $1 \%$ for $\mathrm{TiO}_{2}$ and 2 and $20 \%$ for Psil in all brands of toothpaste that contained either $\mathrm{TiO}_{2}$ or Psil
(Lomer, 2002). Based on previous work we assumed the ingestion of toothpaste to average $2.9 \%$ of the amount on the toothbrush (Barhnart et al. 1974).

Thus, from the above, levels of $\mathrm{TiO}_{2}$ and Psil were established in ingested products and these values were added to the nutrient database to enable estimation of their minimum and likely intakes.

\section{Statistical analysis}

Comparisons between the groups using the matched subjects were carried out using a paired $t$ test for normally distributed data (for example, energy and nutrients) and the Mann-Whitney test for non-normally distributed data (for example, dietary microparticles). In all tests significance was assumed where $P<0.05$ and results are expressed as mean values and SD for normally distributed data, or median and interquartile range for non-normally distributed data, unless otherwise indicated. Results for dietary microparticle intakes are presented as those from the diet (food and drink), pharmaceuticals (prescribed and over-the-counter medication), dietary supplements (herbal, vitamin and/ or mineral preparations) and toothpaste.

\section{Results}

Three hundred and two patients with CD were invited to take part in the present study, of which 114 replied and ninety-one were appropriately matched to controls (547 invited; 142 replied). The patients' disease characteristics and medication at the time of the survey are shown in Table 1. Interestingly, height and weight, but not BMI, differed between the groups (Table 2), although the majority of patients ( $n$ 82) had not been diagnosed with CD until adulthood (aged $\geq 18$ years). As previously shown (Breuer-Katschinski et al. 1996), current smoking and a family history of inflammatory bowel disease were significantly increased in patients with $\mathrm{CD} v$. controls (both $P<0 \cdot 01$ ).

\section{Energy and nutrient intakes}

As noted earlier, intakes of energy, protein, fat and carbohydrate did not differ between the two groups (Lomer et al. 2004). Ca intakes were also similar (controls 875 (SD 284) $v$. patients 843 (SD 273) mg/d; $P=0.4$ ) with 70 and $67 \%$ of subjects, respectively, achieving the reference nutrient intake for Ca $(700 \mathrm{mg} / \mathrm{d}$; Department of Health, 1991).

Consistent with previous reports, the intakes of sucrose and dietary fibre, which are broad markers of processed and unprocessed diets, respectively, were significantly different between the two groups. Mean dietary fibre intake was 14 (SD 5) g/d in control subjects and 12 (SD 5) $\mathrm{g} / \mathrm{d}$ in patients $(P=0.001)$ whereas sucrose intake was 45 $(\mathrm{SD} 18)$ and 52 (SD 27) $\mathrm{g} / \mathrm{d}$, respectively $(P=0 \cdot 04)$. The mean intake of total sugars was similar between the groups (controls 103 (SD 35) g/d, patients 105 (SD 41) g/d; $P=0.7$ ).

\section{Dietary microparticle intakes}

The major identified dietary sources of food-additive $\mathrm{TiO}_{2}$ and Psil are shown in Table 3. As expected, $\mathrm{TiO}_{2}$, but not 
Table 1. Characteristics of patients with Crohn's disease (cases)

\begin{tabular}{|c|c|c|c|}
\hline \multirow[b]{2}{*}{ Variable } & & \multicolumn{2}{|c|}{ Cases } \\
\hline & & $n$ & $\%$ \\
\hline \multirow{4}{*}{$\begin{array}{l}\text { Disease } \\
\quad \text { duration (years) }\end{array}$} & Mean & 11 & \\
\hline & SD & 9 & \\
\hline & Median & 8 & \\
\hline & Range & $1-36$ & \\
\hline \multirow{3}{*}{$\begin{array}{l}\text { Previous intestinal } \\
\text { resection }\end{array}$} & 0 & 52 & 57 \\
\hline & 1 & 27 & 30 \\
\hline & $>1$ & 12 & 13 \\
\hline \multirow[t]{2}{*}{ Stoma } & Yes & 3 & 3 \\
\hline & No & 88 & 97 \\
\hline \multirow[t]{5}{*}{ Diagnosis } & $<1$ year & 4 & 4 \\
\hline & $1-5$ years & 31 & 34 \\
\hline & $5-10$ years & 23 & 25 \\
\hline & $10-20$ years & 19 & 21 \\
\hline & $>20$ years & 14 & 15 \\
\hline \multirow[t]{6}{*}{ Last relapse* } & $<1$ month & 17 & 19 \\
\hline & $1-6$ months & 12 & 13 \\
\hline & $6-12$ months & 7 & 8 \\
\hline & $1-2$ years & 26 & 28 \\
\hline & $2-5$ years & 22 & 24 \\
\hline & $>5$ years & 7 & 8 \\
\hline \multirow[t]{8}{*}{ Current therapy } & No medication & 29 & 32 \\
\hline & 5-ASA & 29 & 32 \\
\hline & Corticosteroids & 4 & 4 \\
\hline & Immunosuppressants $\dagger$ & 12 & 13 \\
\hline & $\begin{array}{l}\text { 5-ASA + } \\
\text { corticosteroids }\end{array}$ & 4 & 4 \\
\hline & $\begin{array}{l}\text { 5-ASA }+ \\
\text { immunosuppressants }\end{array}$ & 8 & 9 \\
\hline & $\begin{array}{l}\text { Corticosteroids + } \\
\text { immunosuppressants }\end{array}$ & 2 & 2 \\
\hline & $\begin{array}{l}\text { 5-ASA + corticosteroids + } \\
\text { immunosuppressants }\end{array}$ & 3 & 3 \\
\hline
\end{tabular}

5-ASA, 5-aminosalicylic acid.

* Self-reported most recent relapse.

† Azathioprine, ciclosporin, mercaptopurine or methotrexate.

Psil, was associated with sucrose-rich foods, since brands of foods containing $\mathrm{TiO}_{2}$ ( $n$ 159) contributed a higher average content of sucrose (median $2.0 \mathrm{~g}$ sucrose/d) than brands of food not containing $\mathrm{TiO}_{2}$ ( $n$ 8135; median $0 \mathrm{~g}$ sucrose/d; $P<0.01)$. Despite apparent differences in the intakes of refined foods between the groups, neither the intake of food-additive $\mathrm{TiO}_{2}$ nor Psil differed between patients and controls (Figs. 1 and 2). Notably, in both groups the intake of food-additive microparticles varied greatly, but only two patients and five controls ingested no $\mathrm{TiO}_{2}$ or Psil during the $7 \mathrm{~d}$ study period.

Of the subjects, $29 \%$ of controls and $4 \%$ of patients took no oral pharmaceuticals or dietary supplements. The main pharmaceutical sources of $\mathrm{TiO}_{2}$ and Psil are shown in Table 4 and $50 \%$ of these were taken only by patients with CD. Intake of pharmaceutical-derived Psil, but not $\mathrm{TiO}_{2}$, was greater in patients than controls (Figs. 1 and 2). Intake of $\mathrm{TiO}_{2}$ from pharmaceuticals was similar to that from the diet while, for Psil, pharmaceutical exposure exceeded dietary exposure, especially in patients (Figs. 1 and 2).

Thirty-three controls and thirty-nine patients ingested at least one dietary supplement daily; typically multivitamins (fourteen controls; thirteen patients) or mineral preparations (three controls; eleven patients), the remainder being vitamin-mineral combinations or herbal preparations. The contribution of dietary supplements to $\mathrm{TiO}_{2}$ and Psil intake approached the contribution from dietary sources and did not differ between the groups (Figs. 1 and 2).

Finally, toothpaste was considered as a possible source of gastrointestinal exposure to inorganic microparticles and qualitatively and quantitatively was similar between the groups (Table 5 and data not shown). Toothpaste was estimated as a low contributor of $\mathrm{TiO}_{2}$ intake but a potentially major contributor of Psil intake (Fig. 2).

Overall, likely total dietary (i.e. dietary, pharmaceutical and toothpaste) intakes (median) of $\mathrm{TiO}_{2}$ and Psil were 2.5 and $35 \mathrm{mg} / \mathrm{d}$, respectively, suggesting similar ingestion levels to previous estimates from per capita estimates $\left(\mathrm{TiO}_{2} 5.4 \mathrm{mg} /\right.$ individual per $\mathrm{d}$ and Psil $32.3 \mathrm{mg} /$ individual per d; Ministry of Agriculture, Fisheries \& Food, 1993).

\section{Discussion}

The present study is the first to investigate human exposure to food-additive dietary microparticles. Previous food-additive intake studies have not assessed intakes of $\mathrm{TiO}_{2}$ or Psil (Lawrie \& Rees, 1996; Lowik, 1996; Lambe et al. 1998; Gibney, 1999). Therefore, per capita estimates, provided from food-additive manufacturers and the food industry $\left(\mathrm{TiO}_{2} 5.4 \mathrm{mg} /\right.$ individual per $\mathrm{d}$ and Psil $32.3 \mathrm{mg} /$ individual per d), are the only values available (Ministry of Agriculture, Fisheries \& Food, 1993). These values cannot take account of the variation within the population (Lambe et al. 1998). The present data now show that likely median $\mathrm{TiO}_{2}$ and Psil intakes are broadly similar to per capita estimates ( 2.5 and $35 \mathrm{mg} /$ individual per $\mathrm{d}$, respectively) but there is wide variation in intakes between individuals $\left(\mathrm{TiO}_{2}\right.$ 0-112 mg/individual per $\mathrm{d}$; Psil $0-254 \mathrm{mg} /$ individual per $\mathrm{d}$ in the present study).

There were three major reasons to initiate the present study. First, we wished to provide accurate estimates of microparticle intake in the modern Western world. We used a $7 \mathrm{~d}$ food record, which is considered sufficient time to obtain dietary habits (Marr \& Heady, 1986) and is comparable with $16 \mathrm{~d}$ weighed records (Bingham et al. 1997). Other studies using dietary recall are prone to reporter error (Kasper \& Sommer, 1979; Silkoff et al. 1980; Jarnerot et al. 1983) and the accuracy of information is dependent on subjects being able to remember precise details and portion sizes of foods. Overall, the present data appeared typical for macronutrient intakes in the UK (Department of Health, 1991) and confirmed the increased intake of sucrose and reduced intake of dietary fibre in the population with $\mathrm{CD}$, both of which probably result from dietary changes in the disease group (Ballegaard et al. 1997). In addition, we confirmed the greater prevalence of smoking and family history of inflammatory bowel disease in subjects with $\mathrm{CD}$, both of which appear related to disease aetiology (Cosnes et al. 1999; Oostenbrug et al. 2003). These findings suggest that we investigated a typical cohort of patients while controls were carefully matched. It should be noted, however, that it is not easy to recruit a completely unbiased population for the control group. In fact, the GP-based controls in the present study had a lower than expected incidence of smoking (13 v. $26 \%$ 
Table 2. Characteristics of controls and patients with Crohn's disease (cases)

\begin{tabular}{|c|c|c|c|c|c|c|c|}
\hline \multirow{2}{*}{ Variable } & & \multicolumn{2}{|c|}{$\begin{array}{c}\text { Controls } \\
(n 91)\end{array}$} & \multicolumn{2}{|c|}{$\begin{array}{l}\text { Cases } \\
(n 91)\end{array}$} & \multicolumn{2}{|c|}{$\begin{array}{l}\text { All subjects } \\
\quad(n 182)\end{array}$} \\
\hline & & $n$ & $\%$ & $n$ & $\%$ & $n$ & $\%$ \\
\hline \multirow[t]{3}{*}{ Age (years) } & Mean & \multicolumn{2}{|c|}{$43 \cdot 8$} & \multicolumn{2}{|c|}{41.4} & & \\
\hline & SD & \multirow{2}{*}{\multicolumn{2}{|c|}{$\begin{array}{c}11 \cdot 8 \\
23-66\end{array}$}} & \multicolumn{2}{|c|}{$12 \cdot 2$} & & \\
\hline & Range & & & \multicolumn{2}{|c|}{$23-65$} & & \\
\hline \multirow{2}{*}{ Height (m) } & Mean & \multicolumn{2}{|c|}{171} & \multirow{2}{*}{\multicolumn{2}{|c|}{$\begin{array}{c}166^{*} \\
9\end{array}$}} & & \\
\hline & SD & \multicolumn{2}{|c|}{9} & & & & \\
\hline \multirow[t]{2}{*}{ Weight (kg) } & Mean & \multicolumn{2}{|c|}{$70 \cdot 7$} & \multicolumn{2}{|c|}{$64.7^{\star}$} & & \\
\hline & SD & \multicolumn{2}{|c|}{$16 \cdot 1$} & \multicolumn{2}{|c|}{$12 \cdot 6$} & & \\
\hline \multirow[t]{2}{*}{ BMI $\left(\mathrm{kg} / \mathrm{m}^{2}\right)$} & Mean & \multirow{2}{*}{\multicolumn{2}{|c|}{$\begin{array}{c}24 \cdot 1 \\
3 \cdot 7\end{array}$}} & \multicolumn{2}{|c|}{$23 \cdot 3$} & & \\
\hline & SD & & & & & & \\
\hline \multirow[t]{3}{*}{ Family history ${ }^{* \star} \dagger$} & None & 88 & 97 & 73 & 80 & & \\
\hline & 1st degree relative & 0 & & 12 & 13 & & \\
\hline & 2nd degree relative & 3 & 3 & 6 & 7 & & \\
\hline \multicolumn{8}{|l|}{ Smoking/status* ${ }^{*}$} \\
\hline & Smokers & 12 & 13 & 27 & 30 & & \\
\hline & Non-smokers & 79 & 87 & 64 & 70 & & \\
\hline \multicolumn{8}{|c|}{ Matched characteristics } \\
\hline \multirow[t]{2}{*}{ Sex } & Male & & & & & 30 & 33 \\
\hline & Female & & & & & 61 & 67 \\
\hline \multirow[t]{5}{*}{ Social class } & I & & & & & 8 & 9 \\
\hline & II & & & & & 47 & 52 \\
\hline & III Manual and non-manual & & & & & 33 & 36 \\
\hline & IV & & & & & 0 & \\
\hline & V & & & & & 3 & 3 \\
\hline \multirow[t]{4}{*}{ Ethnicity } & Caucasian & & & & & 88 & 97 \\
\hline & Caribbean & & & & & 1 & 1 \\
\hline & African & & & & & 1 & 1 \\
\hline & Asian & & & & & 1 & 1 \\
\hline
\end{tabular}

Significantly different from controls: ${ }^{\star} P<0.01,{ }^{\star \star} P<0.001$.

$\dagger$ Family history is for inflammatory bowel disease: odds ratio $=7 \cdot 30$. For smoking odds ratio $=2 \cdot 77$.

from national statistics for the typical social classes of our population; Rickards et al. 2004). The controls also had a dietary fibre intake $(14 \mathrm{~g} / \mathrm{d})$ lower than the dietary reference value $(18 \mathrm{~g} / \mathrm{d}$; Department of Health, 1991) although not dissimilar to that found in some other studies (for example, $14.5 \mathrm{~g} / \mathrm{d}$; Lund et al. 1999). Therefore, although we found no difference in dietary intake between the subjects with CD and our GP-based controls, it is possible that we missed a difference with the general population. Moreover, the recruitment rate in the controls $(17 \%$ of those approached) was relatively low. Control subjects may preferentially volunteer due to an increased awareness of specific dietary or other health-related habits; nonetheless, this is a limitation in all such studies.

Despite the care taken in subject recruitment and assessment of dietary intakes, microparticle intakes are still not easily calculated because (a) some subjects forgot to record exact manufacturer details of foods ingested and (b) some manufacturers of foods refused to provide information on microparticle content. These problems are

Table 3. Major food sources of dietary microparticles*

\begin{tabular}{lcrlrr}
\hline & \multicolumn{2}{c}{$\mathrm{TiO}_{2}$} & & \multicolumn{2}{c}{ Psil } \\
\cline { 2 - 5 } Food & $\mathrm{mg} /$ person per d & $\%$ & Food & $\mathrm{mg} /$ person per d & $\%$ \\
\hline Coffee whitener & 0.52 & 18 & Salt & 1.30 & 29 \\
Sponge cake, with butter icing & 0.52 & 18 & Drinking chocolate powder & 1.26 & 28 \\
Hard-coated candies & 0.32 & 11 & Chewing gumt & 0.92 & 20 \\
Chewing gumtł & 0.28 & 10 & Instant pot savoury snacks & 0.40 & 9 \\
Marshmallows & 0.27 & 10 & Sugar, icing & 0.30 & 7 \\
Low-fat or fat-free dressings & 0.22 & 8 & Chilli powder & 0.18 & 4 \\
Horseradish sauce & 0.18 & 6 & Potato or maize and starch snacks & 0.04 & 1 \\
Tartar sauce & 0.15 & 5 & Artificial sweeteners & 0.03 & $<1$ \\
Thousand island dressing & 0.14 & 5 & Pork sausages & 0.03 & $<1$ \\
Iced ring doughnuts & 0.06 & 2 & Malted milk drink powder & 0.02 & $<1$ \\
Total & 2.66 & 93 & Total & 4.48 & 99 \\
\hline
\end{tabular}

Psil, mixed silicates (for a detailed definition, see p. 948).

* The average daily intakes of $\mathrm{TiO}_{2}$ and Psil from the ten most common food sources for subjects in either group. Percentages are the contribution to the total $\mathrm{TiO}_{2}$ or Psil intakes.

† Assuming all microparticles within the product are ingested.

$\ddagger$ Crispy shelled chewing gum only. 
(a)

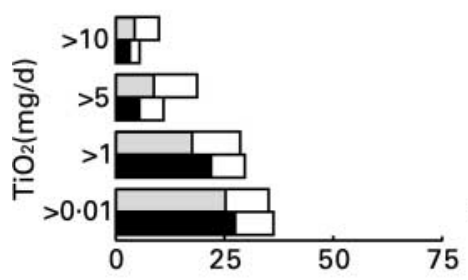

(b)

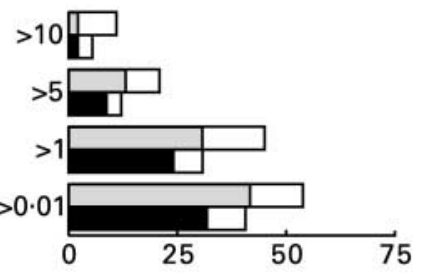

(c)

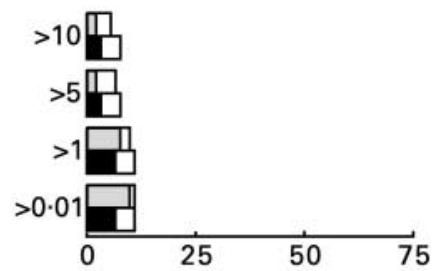

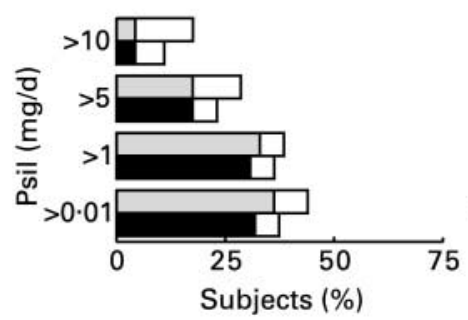
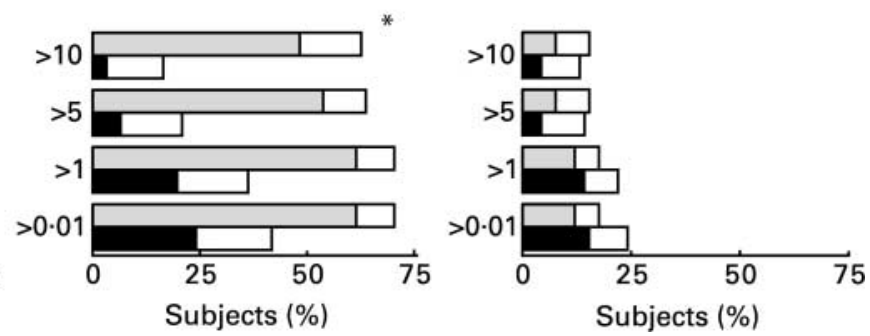

Fig. 1. Cumulative $\mathrm{TiO}_{2}$ and particulate silicate (Psil) intakes from (a) diet, (b) pharmaceuticals and (c) dietary supplements for the control group ( $\square$, minimum; $\square$, likely) and the patients with Crohn's disease ( $\square$, minimum; $\square$, likely), respectively. Statistical tests use likely intakes. Minimum intakes use quantitative data only, and likely intakes use qualitative and quantitative data. For details regarding the 'nutrient and dietary microparticle database', see p. 949 . ${ }^{\star} P<0.001$ at all intakes.
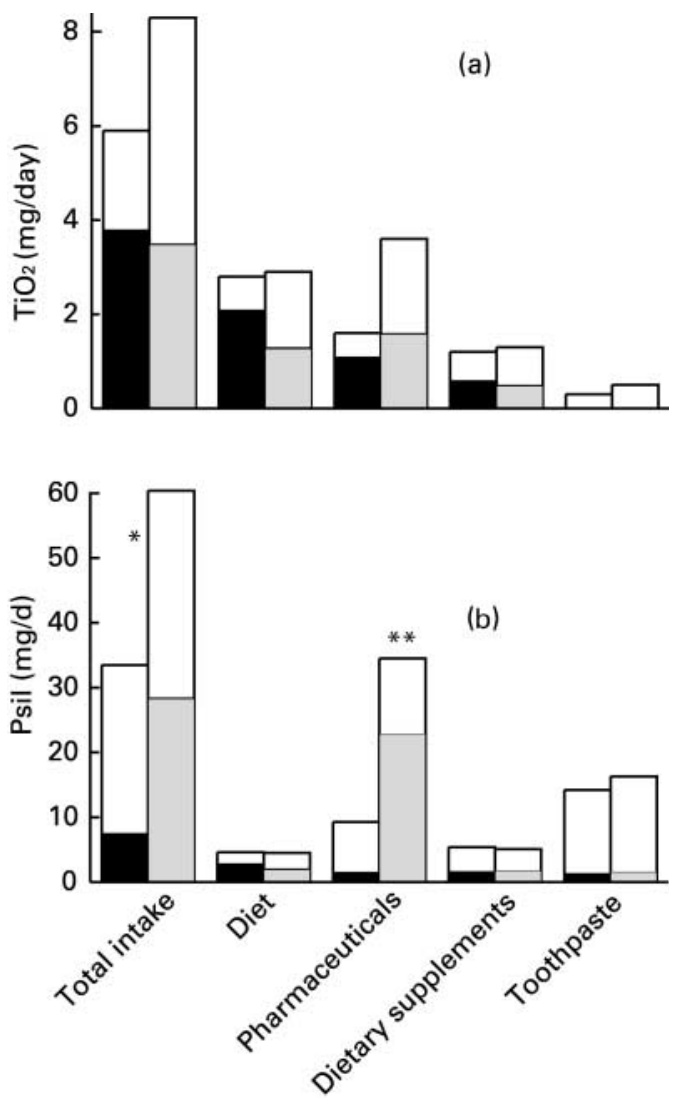

Fig. 2. Intakes of dietary microparticles from all sources. Mean intakes of (a) $\mathrm{TiO}_{2}$ and (b) particulate silicate (Psil) for the control group ( $\mathbf{\square}$, minimum; $\square$, likely) and the patients with Crohn's disease ( $\square$, minimum; $\square$, likely), respectively. Statistical tests use likely intakes. Minimum intakes use quantitative data only, and likely intakes use qualitative and quantitative data. For details regarding the 'nutrient and dietary microparticle database', see p. 949 . ${ }^{\star} P<0.01 ;{ }^{\star *} P<0.001$. likely to be encountered in all studies on food additive intakes, but have not previously been addressed and so we developed a new approach for assessing food-additive microparticle intakes (see p. 949). Data are presented as minimum and likely intakes. Even using minimum estimated intakes the ubiquitous nature of these microparticles in the modern Western diet should not be underestimated. In the present study only $4 \%(7 / 182)$ of subjects ingested no microparticles over the $7 \mathrm{~d}$ period, while a median ingested dose of $43 \mathrm{mg} /$ individual per $\mathrm{d}$ equates to an intake of $10^{12}$ bacterial-sized particles/d. This compares with an estimated total bacterial count in the human gastrointestinal tract of $10^{14}$ (Bengmark, 2001; Shanahan, 2002). Moreover, when compared with lung exposure to particles $\left(20-50 \mu \mathrm{g} / \mathrm{m}^{3} / \mathrm{d}\right)$, which is a well-studied field (Samet et al. 2000), it is noteworthy that (a) the gastrointestinal tract has considerably greater exposure (about 10-fold) and (b) there are specific uptake mechanisms for particles in the distal gastrointestinal tract, namely $\mathrm{M}$ cells (Lomer et al. 2002), that do not exist in the lung. Hence we have proposed that modern Western particulates may be associated with inflammatory diseases of the gut just as ambient air particles are with respiratory disease and CVD (Samet et al. 2000).

Thus our second specific objective was to see whether particle intake differed in subjects with CD $v$. controls. As noted earlier, the most consistent finding in dietary studies in $\mathrm{CD}$ has been that of an increased intake of refined carbohydrate, especially sucrose, compared with the normal population (Martini \& Brandes, 1976; Kasper \& Sommer, 1979; Silkoff et al. 1980; Mayberry et al. 1981; Brauer et al. 1983; Jarnerot et al. 1983; Katschinski et al. 1988; Tragnone et al. 1995), and the present study again confirms this with respect to sucrose. Sucrose-rich foods are (weakly) associated with the food additive $\mathrm{TiO}_{2}$ but we found no evidence for a greater intake of this food additive in patients with CD compared with matched controls. Only in pharmaceutical intake did we 
Table 4. Major pharmaceutical sources of titanium dioxide and mixed silicates (Psil)*

\begin{tabular}{|c|c|c|c|c|c|}
\hline \multirow[b]{2}{*}{ Pharmaceutical } & \multicolumn{2}{|l|}{$\mathrm{TiO}_{2}$} & \multirow[b]{2}{*}{ Pharmaceutical } & \multicolumn{2}{|l|}{ Psil } \\
\hline & $\mathrm{mg} /$ person per $\mathrm{d}$ & $\%$ & & $\mathrm{mg} /$ person per $\mathrm{d}$ & $\%$ \\
\hline Ibuprofen & 0.27 & 20 & Mesalazine $\dagger$ & 9.44 & 77 \\
\hline Co-proxamol & 0.16 & 12 & Paracetamol & 0.71 & 6 \\
\hline Co-codamol & 0.13 & 10 & Azathioprine & 0.50 & 4 \\
\hline Cyclosporin† & 0.11 & 8 & Lansoprazole $†$ & 0.24 & 2 \\
\hline Azathioprine† & 0.09 & 7 & Erythromycint & 0.22 & 2 \\
\hline Codeine phosphate & 0.08 & 6 & Hormone replacement therapy & 0.20 & 2 \\
\hline Loperamide† & 0.08 & 6 & Fe and folic acid & $0 \cdot 16$ & 1 \\
\hline Ranitidine & 0.06 & 5 & Budesonide† & 0.13 & 1 \\
\hline Aspirin & 0.04 & 3 & Diclofenac sodium & $0 \cdot 10$ & 1 \\
\hline Prednisolone $†$ & 0.04 & 3 & Ibuprofen & 0.08 & 1 \\
\hline Total & 1.06 & 80 & Total & 11.78 & 97 \\
\hline
\end{tabular}

${ }^{*}$ Pharmaceuticals providing most of the $\mathrm{TiO}_{2}$ and Psil intakes. Percentages are the contribution to the total $\mathrm{TiO}_{2}$ or $\mathrm{Psil}$ intakes from pharmaceuticals (for detailed definition of Psil, see p. 948). †Only taken by patients with Crohn's disease in the present study.

Table 5. Potential ingestion of dietary microparticles from toothpaste

(Mean values and standard deviations)

\begin{tabular}{|c|c|c|c|c|}
\hline & \multicolumn{2}{|c|}{ Controls } & \multicolumn{2}{|c|}{ Cases } \\
\hline & Mean & SD & Mean & SD \\
\hline $\begin{array}{l}\text { Toothpaste } \\
\text { used (g/d) }\end{array}$ & $2 \cdot 9$ & $2 \cdot 0$ & $3 \cdot 2$ & $1 \cdot 8$ \\
\hline $\begin{array}{l}\text { Assumed ingested } \\
\text { toothpaste }(\mathrm{mg} / \mathrm{d})^{\star}\end{array}$ & $84 \cdot 2$ & 58.4 & $92 \cdot 2$ & $52 \cdot 0$ \\
\hline $\begin{array}{l}\mathrm{TiO}_{2} \text { containing } \\
\text { toothpaste (\% used) }\end{array}$ & \multicolumn{2}{|l|}{35} & \multicolumn{2}{|l|}{45} \\
\hline \multicolumn{5}{|l|}{ Maximum likely } \\
\hline $\begin{array}{c}(\mathrm{mg} / \mathrm{d}) \dagger: \text { Mean } \\
\text { Median }\end{array}$ & \multicolumn{2}{|c|}{$0 \cdot 30$} & \multicolumn{2}{|c|}{$\begin{array}{l}0.46 \\
0\end{array}$} \\
\hline IQR & \multicolumn{2}{|c|}{$0-0.50$} & \multicolumn{2}{|c|}{$0-0.87$} \\
\hline $\begin{array}{l}\text { Psil-containing } \\
\text { toothpaste (\% used) }\end{array}$ & \multicolumn{2}{|c|}{81} & \multicolumn{2}{|c|}{85} \\
\hline \multicolumn{5}{|l|}{$\begin{array}{l}\text { Maximum likely } \\
\text { ingested Psil }\end{array}$} \\
\hline $\begin{array}{r}(\mathrm{mg} / \mathrm{d}) \ddagger: \text { Mean } \\
\text { Median }\end{array}$ & \multicolumn{2}{|c|}{$\begin{array}{l}14 \cdot 2 \\
11 \cdot 2\end{array}$} & \multicolumn{2}{|c|}{$16 \cdot 3$} \\
\hline IQR & \multicolumn{2}{|c|}{$8 \cdot 4-17.4$} & \multicolumn{2}{|c|}{$8 \cdot 7-19.9$} \\
\hline
\end{tabular}

Psil, mixed silicates (for a detailed definition, see p. 948); IQR, interquartile range.

* Assumed toothpaste ingestion was estimated as $2.9 \%$ of toothpaste used (Barhnart et al. 1974)

† Maximum likely ingested $\mathrm{TiO}_{2}$ was calculated as $1 \%(\mathrm{w} / \mathrm{w})$.

¥ Maximum likely ingested Psil was calculated as $20 \%(\mathrm{w} / \mathrm{w})$.

There were no significant differences.

observe a difference in microparticle exposure to Psil although the significance of this should not be over-interpreted. The finding results from Psil contained in pharmaceuticals which are more likely to be used by subjects with $\mathrm{CD}$ than in a random selection of subjects from GP records. This finding, therefore, is an inevitable consequence in a patient group with $\mathrm{CD}$ compared with a random selection of subjects from GP records and so its significance should not be over-interpreted. We found no other evidence for increased intakes of microparticles in subjects with CD compared with controls, including no difference in the amount or type of toothpaste used, which is an issue that has received some attention
(Sullivan, 1990). Overall, in both subject groups, microparticle intake was highly variable and there was a large overlap between the groups in total intakes.

Although increased exposure to particles may be associated with an increased risk of particle-related diseases (for example, pneumoconiosis), much evidence also supports an abnormal, idiosyncratic response. Our findings lay foundations for the design of a particle-free diet that can be studied in CD. This was the third reason to undertake the present study.

In a previous pilot study we suggested that a particlefree diet supports disease remission in subjects with CD. Overall, however, that trial largely compared an unprocessed diet with a habitual modern Western diet (Lomer et al. 2001). Identification of the foods that contain microparticles now allows a dietary microparticle-free study to be better targeted. In addition, we can identify which toothpastes and medications are particle-free and utilise these within such a study. Such a multi-centre trial is completed and the results will be presented shortly.

The present study has shown that the use of $\mathrm{TiO}_{2}$ and Psil in the food industry is limited to a discrete range of foods and, perhaps, in future work, a short and simple-touse food-frequency questionnaire could be developed to determine dietary microparticle intakes from foods. For pharmaceuticals, dietary supplements and toothpaste this is more difficult but manufacturers may be encouraged to make available lists of excipients.

Finally, the present data also revealed other interesting findings. Dietary Ca intake was carefully assessed, as this can act as a bridging ion between microparticles and luminal antigens present in the gastrointestinal tract (Evans et al. 2002), as well as precipitating with phosphate to form endogenous de novo microparticles in the intestinal lumen (Evans et al. 2002; Lomer et al. 2002). However, there was no significant difference in intake of Ca between subjects with CD and controls. Only two previous studies have assessed $\mathrm{Ca}$ intake in $\mathrm{CD}$ and both showed similar results with mean daily intakes meeting recommended levels (Gee et al. 1985; Reif et al. 1997).

The nutritional status of patients with CD is often compromised, even in disease remission (Geerling et al. 1998), 
where there is evidence that patients can still experience weight loss and often have a low BMI $\left(\leq 19 \mathrm{~kg} / \mathrm{m}^{2}\right.$; Mingrone et al. 1999). Although a comprehensive nutritional assessment was not carried out in the present study, it was interesting to note that patients with CD were significantly shorter and weighed significantly less than their matched controls, despite a similar BMI. Thus the disease may be undiagnosed or poorly treated in the early years of life, leading to poor growth.

In conclusion, the cause of $\mathrm{CD}$ remains elusive, and whether certain aspects of the diet exacerbate symptoms is difficult to identify due to the nature and complexity of dietary habits. We have proposed that an abnormal response to dietary microparticles may be one such factor. These findings now show that microparticle intake does not vary in patients with CD $v$. controls. Further studies will therefore focus on the assessment of whether this normal intake of dietary microparticles may still exacerbate or trigger symptoms in subjects with an underlying susceptibility to $\mathrm{CD}$. The use of low-microparticle diets, based on findings from the present study, will facilitate such investigations.

\section{Acknowledgements}

We thank Drs Jeremy Sanderson and John Meenan at Guy's and St Thomas' NHS Trust, London and Dr Peter McIntyre at Queen Elizabeth II Hospital, Welwyn Garden City, Hertfordshire for access to their CD patient databases. We also thank Professor Roger Jones at Lambeth Group Practice, London and Dr Roger Aubrey at Bridge Cottage Surgery, Welwyn, Hertfordshire for inviting their patients to take part as controls. M. C. E. L. was a research training fellow funded by the NHS Executive London Regional Office.

\section{References}

Anderson SHC, Elliott H, Wallis DJ, Canham LT \& Powell JJ (2003) Dissolution of different forms of partially porous silicon wafers under simulated physiological conditions. Phys Stat Sol 197, 331-335.

Ballegaard M, Bjergstrom A, Brondum S, Hylander E, Jensen L \& Ladefoged K (1997) Self-reported food intolerance in chronic inflammatory bowel disease. Scand J Gastroenterol 32, 569-571.

Barhnart WE, Hiller LK, Leonard GJ \& Michaels SE (1974) Dentifrice usage and ingestion among four age groups. $J$ Dental Res 53, 1317-1322.

Bengmark S (2001) Pre-, pro- and synbiotics. Curr Opin Clin Nutr Metab Care 4, 571-579.

Bingham SA, Gill C, Welch A, et al. (1997) Validation of dietary assessment methods in the UK arm of EPIC using weighed records, and 24-hour urinary nitrogen and potassium and serum vitamin $\mathrm{C}$ and carotenoids as biomarkers. Int J Epidemiol 26, S137-S151.

Brauer PM, Gee MI, Grace M \& Thomson AB (1983) Diet of women with Crohn's and other gastrointestinal diseases. $J$ Am Diet Assoc 82, 659-664.

Breuer-Katschinski BD, Hollander N \& Goebell H (1996) Effect of cigarette smoking on the course of Crohn's disease. Eur J Gastroenterol Hepatol 8, 225-228.
Cosnes J, Carbonnel F, Carrat F, Beaugerie L, Cattan S \& Gendre J (1999) Effects of current and former cigarette smoking on the clinical course of Crohn's disease. Aliment Pharmacol Ther 13, 1403-1411.

Department of Health (1989) Dietary Sugars and Human Disease. Report on Health and Social Subjects no. 37. London: H.M. Stationery Office.

Department of Health (1991) Dietary Reference Values for Food Energy and Nutrients for the United Kingdom. Report on Health and Social Subjects no. 41. London: H.M. Stationery Office.

Ellis RD, Goodlad JR, Limb GA, Powell JJ, Thompson RP \& Punchard NA (1998) Activation of nuclear factor kappa B in Crohn's disease. Inflamm Res 47, 440-445.

Evans SM, Ashwood P, Warley A, Berisha F, Thompson RP \& Powell JJ (2002) The role of dietary microparticles and calcium in apoptosis and interleukin-1beta release of intestinal macrophages. Gastroenterology 123, 1543-1553.

Gee MI, Grace MG, Wensel RH, Sherbaniuk RW \& Thomson AB (1985) Nutritional status of gastroenterology outpatients: comparison of inflammatory bowel disease with functional disorders. J Am Diet Assoc 85, 1591-1599.

Geerling BJ, Badart-Smook A, Stockbrugger RW \& Brummer RJ (1998) Comprehensive nutritional status in patients with longstanding Crohn disease currently in remission. Am J Clin Nutr 67, 919-926.

Gibney MJ (1999) Dietary intake methods for estimating food additive intake. Regul Toxicol Pharmacol 30, S31-S33.

Gibson GR \& Roberfroid MB (1995) Dietary modulation of the human colonic microbiota: introducing the concept of prebiotics. J Nutr 125, 1401-1412.

Hampe J, Grebe J, Nikolaus S, et al. (2002) Association of NOD2 (CARD 15) genotype with clinical course of Crohn's disease: a cohort study. Lancet 359, 1661-1665.

Harper PH, Lee EC, Kettlewell MG, Bennett MK \& Jewell DP (1985) Role of the faecal stream in the maintenance of Crohn's colitis. Gut 26, 279-284.

Holland B, Welch AA, Unwin ID, Buss DH, Paul AA \& Southgate DAT (1991) McCance and Widdowson's The Composition of Foods, 5th ed., London: The Royal Society of Chemistry.

Inohara N, Ogura Y, Fontalba A, et al. (2003) Host recognition of bacterial muramyl dipeptide mediated through NOD2. Implications for Crohn's disease. J Biol Chem 278, 5509-5512.

Jarnerot G, Jarnmark I \& Nilsson K (1983) Consumption of refined sugar by patients with Crohn's disease, ulcerative colitis, or irritable bowel syndrome. Scand J Gastroenterol 18, 999-1002.

Jukes DJ (1997) Food Legislation of the UK: A Concise Guide, 4th ed., Oxford: Butterworth-Heinemann.

Kasper H \& Sommer H (1979) Dietary fibre and nutrient intake in Crohn's disease. Am J Clin Nutr 32, 1898-1901.

Katschinski B, Logan RF, Edmond M \& Langman MJ (1988) Smoking and sugar intake are separate but interactive risk factors in Crohn's disease. Gut 29, 1202-1206.

Kovacsovics-Bankowski M, Clark K, Benacerraf B \& Rock KL (1993) Efficient major histocompatibility complex class I presentation of exogenous antigen upon phagocytosis by macrophages. Proc Natl Acad Sci U S A 90, 4942-4946.

Lambe J, Kearney J, Becker W, Hulshof K, Dunne A \& Gibney MJ (1998) Predicting percentage of individuals consuming foods from percentage of households purchasing foods to improve the use of household budget surveys in estimating food chemical intakes. Public Health Nutr 1, 239-247.

Lawrie CA \& Rees NM (1996) The approach adopted in the UK for the estimation of the intake of food additives. Food Addit Contam 13, 411-416. 
Lomer MCE (2002) Dietary microparticles and Crohn's disease. $\mathrm{PhD}$ Thesis, University of London.

Lomer MCE, Harvey RSJ, Evans SM, Thompson RPH \& Powell JJ (2001) Efficacy and tolerability of a low microparticle diet in a double blind, randomized, pilot study in Crohn's disease. Eur J Gastroenterol Hepatol 13, 101-106.

Lomer MCE, Kodjabashia K, Hutchinson C, Thompson RPH \& Powell JJ (2004) Intake of dietary iron is low in patients with Crohn's disease: a case-control study. Br J Nutr 91, $141-148$.

Lomer MCE, Thompson RPH, Commisso J, Keen CL \& Powell JJ (2000) Determination of titanium dioxide in foods using inductively coupled plasma optical emission spectrometry. Analyst 125, 2339-2343.

Lomer MCE, Thompson RPH \& Powell JJ (2002) Fine and ultrafine particles of the diet: influence on the mucosal immune response and association with Crohn's disease. Proc Nutr Soc 61, $123-130$.

Lowik MR (1996) Possible use of food consumption surveys to estimate exposure to additives. Food Addit Contam 13, 427-441.

Lund EK, Wharf SG, Fairweather-Tait S \& Johnson IT (1999) Oral ferrous sulfate supplements increase the free radicalgenerating capacity of feces from healthy volunteers. Am J Clin Nutr 69, 250-255.

Marr JW \& Heady JA (1986) Within- and between-person variation in dietary surveys: number of days needed to classify individuals. Hum Nutr Appl Nutr 40, 347-364.

Martini GA \& Brandes JW (1976) Increased consumption of refined carbohydrates in patients with Crohn's disease. Klin Wochenschr 54, 367-371.

Mayberry JF, Rhodes J, Allan R, Newcombe RG, Regan GM, Chamberlain LM \& Wragg KG (1981) Diet in Crohn's disease: two studies of current and previous habits in newly diagnosed patients. Dig Dis Sci 26, 444-448.

Mingrone G, Capristo E, Greco AV, Benedetti G, De Gaetano A, Tataranni PA \& Gasbarrini G (1999) Elevated diet-induced thermogenesis and lipid oxidation rate in Crohn disease. Am J Clin Nutr 69, 325-330.

Ministry of Agriculture, Fisheries and Food (1993) Dietary Intake of Food Additives in the UK: Initial Surveillance. Food Surveillance Paper no. 37. London: H.M. Stationery Office.

Oostenbrug LE, van Dullemen HM, te Meerman GJ \& Jansen PL
(2003) IBD and genetics: new developments. Scand J Gastroenterol 239, Suppl., 63-68.

Powell JJ, Ainley CC, Harvey RS, Mason IM, Kendall MD, Sankey EA, Dhillon AP \& Thompson RP (1996) Characterisation of inorganic microparticles in pigment cells of human gut associated lymphoid tissue. Gut 38, 390-395.

Rayment N, Mylonaki M, Hudspith B, Brostoff J \& Rampton DS (2003) Co-localisation of Escherichia coli with macrophages in lamina propria in patients with active inflammatory bowel disease (IBD). Gut 52, A13.

Reid I (1980) Social class, ethnicity, sex, and age in empirical research. In Social Class Differences in Britain; Life-chances \& Lifestyles, pp. 27-89. London: Fontana Press.

Reif S, Klein I, Lubin F, Farbstein M, Hallak A \& Gilat T (1997) Pre-illness dietary factors in inflammatory bowel disease. Gut 40, 754-760.

Rickards L, Fox K, Roberts C, Fletcher L \& Goddard E (2004) General Household Survey, Living in Britain, 2002. London: H.M. Stationery Office.

Samet JM, Dominici F, Curriero FC, Coursac I \& Zeger SL (2000) Fine particulate air pollution and mortality in 20 U.S. cities, 1987-1994. $N$ Engl J Med 343, 1742-1749.

Shanahan F (2002) Probiotics and inflammatory bowel disease: from fads and fantasy to facts and future. Br J Nutr $\mathbf{8 8}$, Suppl. 1, S5-S9.

Shepherd NA, Crocker PR, Smith AP \& Levison DA (1987) Exogenous pigment in Peyer's patches. Hum Pathol 18, 50-54.

Silkoff K, Hallak A, Yegena L, Rozen P, Mayberry JF, Rhodes J $\&$ Newcombe RG (1980) Consumption of refined carbohydrate by patients with Crohn's disease in Tel-Aviv-Yafo. Postgrad Med $J$ 56, 842-846.

Sullivan SN (1990) Hypothesis revisited: toothpaste and the cause of Crohn's disease. Lancet 336, 1096-1097.

Taylor PD, Jugdaohsingh R \& Powell JJ (1997) Soluble silica with high affinity for aluminium under physiological and natural conditions. J Am Chem Soc 119, 8852-8856.

Tragnone A, Valpiani D, Miglio F, Elmi G, Bazzocchi G, Pipitone E \& Lanfranchi GA (1995) Dietary habits as risk factors for inflammatory bowel disease. Eur J Gastroenterol Hepatol 7, 47-51.

Urbanski SJ, Arsenault AL, Green FH \& Haber G (1989) Pigment resembling atmospheric dust in Peyer's patches. Mod Pathol 2, 222-226. 